\title{
Et universitet er et sted, der forsker i alt - undtagen i sig selv og sin egen virksomhed
}

\author{
Anmeldelse af Palle Rasmussen
}

Karen Borgnakke:

Et universitet er et sted, der forsker $i$ alt - undtagen i sig selv og sin egen virksomhed. Rapport om den forskningsfaglige baggrund for udvikling af universitetspædagogisk forskning. Institut for Medier, Erkendelse og Formidling samt Institut for Nordiske Studier og Sprogvidenskab, Københavns Universitet, 2011.

99 sider.

Der er tale om en forskningsrapport, hvis formål er at kortlægge videnskabelige miljøer, forskningsprogrammer og forskningsgrupper inden for de universitetspædagogiske områder samt at give et overblik over hovedtendenser og eksempler på toneangivende og perspektivrige forskningsområder og projekter. Rapporten bygger først og fremmest på tilgængelig dansk litteratur og forskning på området fra 70'erne og frem men også på indtryk fra forskningsrejser til flere internationale centre for universitetspædagogik, hvoraf især miljøer ved universiteterne Oslo, Berkeley og Stanford præsenteres i rapporten.

Rapporten er opbygget i tre dele. Den første handler om universitetspædagogisk forskning 'som forskning' med behandling af dens videnskabelige forankring (som Borgnakke bl.a. ser som interdisciplinær), dens skiftende paradigmer og dens organisatoriske tilhørssteder. Anden del handler om tendenser og temaer i forskningsfeltet med hovedvægt på dansk sammenhæng men med inddragelse af internationale tilgange og eksempler. Afgrænsningen mellem første og anden del lyder måske ikke så entydig, og det er den heller ikke. Det er i vidt omfang samme litteratur, projekter og forskningsmiljøer som diskuteres i de to dele. Borgnakke forsøger at bruge paradigmer og paradigmeskift som indfaldsvinkel i første del, temaer og strategier som indfaldsvinkel i anden del. Det fungerer dog kun til en vis grad, og derfor kan det være svært at følge den røde tråd i de to første dele. Den tredje del, som er noget kortere, er lettere at læse, fordi den diskuterer potentialer i universitetspædagogisk forskning via behandling af tre bestemte forsknings- og udviklingsmiljøer: Nemlig Aalborg Universitet, den universitetspædagogiske enhed ved Universitetet i Oslo og forskningscenteret H-STAR ved Stanford Universitet.

Rapporten kommer vidt omkring. Borgnakke konstaterer i forordet, at det universitetspædagogiske felt "ikke sådan lader sig overskue". Det har hun ret i, og overskue- 
ligheden bliver ikke større af, at hun ikke kun vil fremstille den forskning, som eksplicit kalder sig selv universitetspædagogisk; hun vil også indplacere den i forhold til forskningen i uddannelse, pædagogik og læring mere generelt. Det er en rigtig bestræbelse, synes jeg. Man kan måske indvende, at flere af de universitetspædagogiske enheder, der har virket i Danmark de sidste 20 år, både i deres opgaver og deres medarbejderstab har haft begrænset tilhørsforhold til den institutionaliserede pædagogiske forskning. Men den universitetspædagogiske praksis og refleksion har alligevel trukket på forskningen og metoderne inden for didaktik, pædagogisk psykologi, læringsteori og andre dele af det pædagogiske forskningsfelt. Så det er prisværdigt, at Borgnakke anlægger det brede perspektiv; men det gør ikke kortlægningsopgaven lettere, og det har ikke øget overskueligheden i forskningsrapporten.

Det centrale i rapportens første del er forsøget på at lokalisere de væsentligste paradigmer, som har præget universitetspædagogisk forskning. Paradigmebegrebet, hentet fra Thomas Kuhn, præsenteres kort, og Borgnakke argumenterer for, at der i perioden 1970-2010 har eksisteret tre stærke paradigmer (s. 15), nemlig først det projektpædagogiske paradigme, dernæst læringsparadigmet samt endelig paradigmet universitet og samfund, som hun også kalder 'den politologiske vending' (s. 32). Der har selvsagt også eksisteret andre tilgange, men de har ikke haft sammenhæng og styrke nok til at fremstå som paradigmer. Borgnakke præsenterer og diskuterer især læringsparadigmet. Hun identificerer det med den angelsaksiske tradition, som har Paul Ramsden og John Biggs som centrale repræsentanter. Traditionen henter inspiration fra generel pædagogisk forskning, herunder ikke mindst Ference Martons læringsforståelse. Dette teoretiske grundlag bliver dog ikke videreudviklet, siger Borgnakke, derimod tages det som udgangspunkt for anvendelsesorienterede begreber og retningslinjer som f.eks. SOLO-taksonomien og 'constructive alignment'. Borgnakke finder, at Biggs-traditionen mangler udsyn og ikke tager højde for de mange andre tilgange til læring, som har præget den pædagogiske forskning de seneste 10-15 år, herunder sociokulturelle tilgange som situeret læring og mesterlære. Kritikken er relevant nok, men behandlingen af læringsparadigmet illustrerer samtidig, at Borgnakke kan være lidt for hurtig til at bevæge sig fra den nøgterne kortlægning af paradigmer til kritik af de positioner, hun ikke deler.

I rapportens anden del søger Borgnakke som nævnt at fremstille de temaer og strategier, som har præget den universitetspædagogiske forskning i perioden. Også her sker det i sammenhæng med uddannelsesforskningen i bredere forstand, hvor hun peger på en bevægelse fra 70'ernes kritiske analyser af forholdet mellem uddannelse og samfund på makroplan og på mikroplan over den gradvise opdagelse af temaer som kønnets betydning, etnicitetens betydning og uddannelse som system og organisation (s. 43). Det har nok en vis gyldighed for uddannelsesforskningen bredt, men jeg synes ikke det bliver dokumenteret, at denne bevægelse i samme grad har kende- 
tegnet universitetspædagogisk forskning. Mere interessant er behandlingen af de forskellige behov og interesser, universiteterne markerer i forhold til universitetspædagogik og universitetspædagogisk forskning. Eller måske snarere: Som universiteterne ikke markerer; for Borgnakke konstaterer flere gange, at hverken universiteterne selv eller de senere års strategiske uddannelsesforskning i nævneværdigt omfang har kvalificeret og styrket universitetspædagogikken (se fx s. 50 og s. 52). Hun finder, at især to spørgsmål er blevet forsømt: For det første spørgsmålet om, hvordan og i hvilke institutionelle rammer akademiske læreprocesser skal organiseres, og for det andet spørgsmålet om didaktisk og fagdidaktisk forskning og dennes rolle. I forhold til det sidstnævnte spørgsmål kan man indvende, at netop Biggs-traditionen, som Borgnakke identificerer med læringsparadigmet, vel nok så meget er en didaktisk tilgang, selv om den ikke knytter an til den tyske didaktik-tradition.

Hvad angår spørgsmålet om fagdidaktik, må man sige, at meget af den danske universitetspædagogiske forskning netop er fagdidaktisk i den forstand, at den er tæt knyttet til vidensindhold og forståelsesformer inden for bestemte fagområder som for eksempel matematik, ingeniørvidenskab og fremmedsprog. Problemet er ikke mangel på fagdidaktisk forskning men mangel på faglig sammenhæng mellem denne forskning og den generelle forskning i læring, uddannelse og pædagogik. Det er også Borgnakkes pointe, tror jeg.

Rapportens tredje del, med gennemgang og diskussion af udviklingen i tre bestemte forsknings- og udviklingsmiljøer, er instruktiv. Jeg må dog sige, at efter de mange kritiske kommentarer i første og anden del fremstår tredje del overraskende positiv og optimistisk på den universitetspædagogiske forsknings vegne. Borgnakke gør ganske vist tydeligt opmærksom på, at hun har udvalgt tre 'gode' eksempler; men også disse miljøer og centre har vel mødt og måttet forholde sig til de vanskeligheder og tvetydigheder, som bliver påpeget i rapportens første og anden del?

Man skal ikke læse denne rapport for at få et hurtigt overblik over den universitetspædagogiske forskning og dens udvikling. Den rummer bestemt bidrag til et sådant overblik; der er beskrivelser af udviklinger, miljøer og projekter, og en omfattende liste af referencer bliver nævnt og indplaceret. Men rapportens springende, komplekse og digressionsprægede fremstilling vanskeliggør overblikket. Man skal snarere læse rapporten som en række skarpe analyser af dilemmaer, vanskeligheder og potentialer i udviklingen af universitetspædagogisk praksis og forskning. Og som en samling af argumenter for den pointe, at universitetspædagogisk forskning må have en solid og reflekteret forankring i generel forskning om læring, uddannelse og pædagogik. Det er både en rigtig og en vigtig pointe. 